UDC 621.43.031.3(045)

DOI https://doi.org/10.32838/2663-5941/2021.2-1/09

Olali N.V.

Niger Delta University

Osaisai E.F.

Niger Delta University

Olali M.O.

Niger Delta University

\title{
SYNTHESIS OF AUTOMATIC SYSTEM OF ANTI-SURGE PROTECTION FOR THE AVIATION GTE
}

Gas-dynamic stability of compressors of aircraft gas turbine engines is one of the most important conditions that determines their reliability and level of flight safety. Pumping phenomena in the gas turbine engine leads to a loss of traction, accompanied by an increase in gas temperature in front of the turbine and an increase in vibration and mass flow along the engine path. The work allows a small probability of surge, but it is proposed to equip gas turbine engines with emergency surge protection systems.

When creating high-pressure compressors, special attention is paid to ensuring high efficiency and the required margin of gas-dynamic stability in the entire range of changes in the modes of operation of the gas turbine engine during operation. The solution to this problem while maintaining large values of the degree of pressure increase in the compressor is associated with the need to ensure optimal flow of the line of operating modes on the characteristics of the engine compressor. When creating an automatic anti-surge system used as a control factor - the change of fuel supply to the combustion chamber of the engine. Because it has the most significant effect on the gas-dynamic stability of the compressor.

The proposed system for controlling the position of the line of operating modes, which can be included as a component in the digital electronic system of automatic control of the engine, which will ensure its gasdynamic stable operation throughout the operating range. To prevent surges, an automatic device is proposed that allows you to detect surges at an early stage-pre-surge. In the work, the pre-surge is considered as the transition of the operating point across the boundary of the design margin of stability in this mode of operation of the engine. The adiabatic efficiency of the compressor is considered as a diagnostic sign of pre-surge. The device for implementing this algorithm registers the values of pressures and temperatures of the inhibited flow at the inlet and outlet of the compressor and the speed of the rotor. It is proposed to use an ionic anemometer to measure the flow rate.

The capabilities of the proposed system can be expanded by using a temperature sensor of the inhibited flow behind the compressor. That is, the developed combined device based on an ionic anemometer can be used both to solve the problem of determining the actual margin of gas-dynamic stability of the compressor stage and as a sensitive element of the control system of aviation gas turbine engines, which prevent surges.

Key words: aircraft gas turbine engine, surge, pre-surge, gas-dynamic stability, line of operating modes, automatic surge warning device.

Introduction. Gas-dynamic stability of compressors of aircraft gas turbine engines (GTE) is one of the most important conditions that determines their reliability and level of flight safety. Unstable operation of the compressor in the engine system, the so-called surge, causes intense fluctuations in the pressure of the working fluid in the flow part or gas-dynamic shocks. Surge is the cause of engine shutdown in flight, fire or burning of the turbine blades $[1 ; 2]$.

Analysis of the causes of surge compressors of aircraft GTE shows that in most cases in the process of development of this phenomenon there are events that consistently complicate the situation in flight. According to statistics [1], more than $70 \%$ of aviation events occur due to a combination of several adverse factors. Usually this set of several different factors is related to the activity of the crew, the functional efficiency of the GTE and flight conditions.

Analysis of research and publications. As shown by the results of studies presented in [1-4], surge phenomena in the GTE lead to thrust penalty, accompanied by an increase in gas temperature in front of the turbine and increased vibration levels as a result of large amplitudes of pressure pulsations and 
mass flow through the engine passage. The possibility of these phenomena is a serious obstacle to increasing the reliability of the GTE in particular and flight safety in general (4).

Short-term loss of thrust in the event of a surge on one of the engines for a multi-engine aircraft or even for a single-engine in the case of sufficient to bleed off the reserves of altitude and speed does not lead to a catastrophic situation [1]. However, an increase in the temperature in the turbine and an increase in vibration can lead to burnout of the turbine nozzles and other failures [2]. Usinf aircraft experience [2-4] shows that especially unacceptable for the engine is an unacceptable increase in gas temperature in front of the turbine.

Setting objectives. To increase the stability margins of the aircraft reserve factor the following options are used $[4 ; 6]$ : control of the compressor guides, air bleed off from the individual booster spool, adjustable dosing of fuel supply at start-up modes, throttle intake, etc. These measures reduce the likelihood of surges, but cannot guarantee their elimination, as surges may be the result of failures in the systems themselves to prevent disruptions. In addition, the increase in stability margins leads to a significant reduction in the efficiency of the compressor and, accordingly, the efficiency of the GTE [4].

Therefore, it is advisable to allow a small probability of surge, but to equip the GTE with emergency surge protection systems and ensure maximum efficiency of the engines [6].

Thus, we formulate the research objectives as the following - to create an automatic system of antisurge protection for the aircraft GTE.

Automatic anti-surge protection system for the aviation GTE.

When creating high-pressure compressors, special attention is paid to ensuring high efficiency and the required margin of gas-dynamic stability in the entire range of changes in the modes of operation of the gas turbine engine during operation. The solution to this problem while maintaining large values of the degree of pressure increase in the compressor is associated with the need to ensure optimal flow of the operating line (OL) on the characteristics of the engine compressor. The displacement of the OL at the intake leads to a decrease in the stock of gas-dynamic stability of the booster spool. To prevent surges, the displacement of the OL in transient modes must be ensured within safe limits by limiting the rate of change of the engine mode and adjusting the compressor.

Existing aircraft engines do not have high-speed OL position control systems based on the booster spool characteristics. Active control of the AeroDerivative Gas Turbine with digital automatic control systems (ACS).

The most promising are continuous closed control systems for axial compressors in terms of parameters that characterize the state of air flow in the compressor or behind it. The NGTE Institute, together with Rolls-Royce and General Electric, has conducted tests to substantiate the feasibility of using the number $\mathrm{M}$ on a compressor or its individual spool as an adjustable parameter.

The application of this parameter in the control systems of the axial compressor is due to the fact that the number $M$ uniquely corresponds to each value of the reduced rotor speed and decreases monotonically when approaching the operating point to the limit of gas-dynamic stability of the compressor. This allows when approaching OL to the limit of stability to form a preemptive command to control the compressor by reducing the number of $M$ to a certain value.

A typical dependence of the number $M$ on the reduced air flow at the inlet to the compressor is shown in fig. 1.

Thus, as controlled parameters in the system of closed control of axial compressors it is supposed to use value of number $M$ of an air stream on each spool of the compressor.

The number $M$ is determined by the formula:

$$
\begin{gathered}
\mathrm{M}=\frac{C}{\sqrt{k R T}}, \\
\text { or } M=\frac{1}{\sqrt{\frac{k R T^{*}}{c^{2}}-\frac{k-1}{2}}} ; \\
\text { or } M=\sqrt{\frac{2}{k-1}\left[\left(\frac{1}{\left.\left.1-\frac{\Delta P}{P_{k}^{*}}\right)^{\frac{k-1}{k}}-1\right]}\right]\right.}
\end{gathered}
$$

where $T=T^{*}-\frac{C^{2}}{\frac{2 k}{k-1} R}$.

To determine the number $M$ of air flow in the cross section of the compressor surge, it is advisable to use the developed combined device (Fig. 1), which allows measuring the temperature of the stagnant flow and its speed, and formula (2). In contrast to the existing method of determining the number $M$ [7] using formula (3) and the ratio of static pressure drop $\Delta p$ to the full $p^{*}$, the proposed method allows to increase the speed of the ACS and the accuracy 


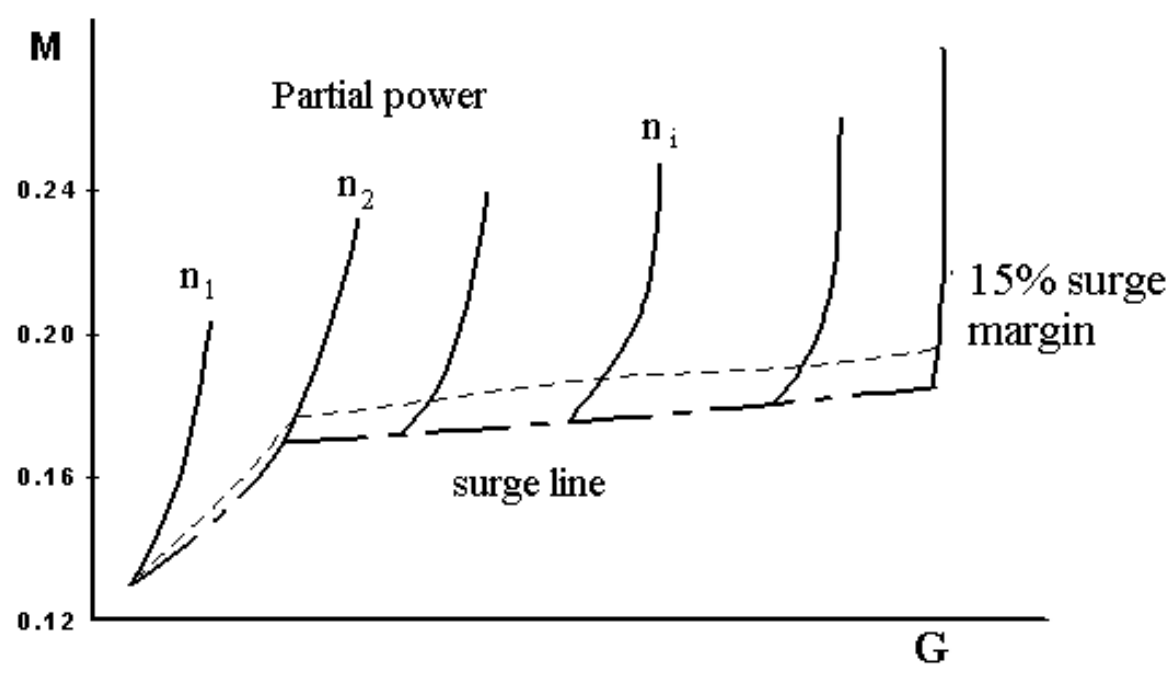

Fig. 1. Compressor characteristics

of measurements by eliminating the operation of smoothing the pressure pulsations of periodically non-stationary air flow.

The following can be used as control factors in compressor operating:

- air passage from the inner circuit of the low pressure compressor (LPC) (from the cavity at the outlet of the connected stages) through the adjustable sash to the outer circuit;

- air passage from the intermediate stages of the high pressure compressor (HPC) in the outer circuit;

- change of angle of installation of blades of the adjustable directing device of the first degree of HPC;

- change of fuel supply to the combustion chamber of the engine.

The first control factor can be used to prevent a surge or rotating failure in the HPC.

The control of the position of the operating line modes of the HPC can be carried out at low engine operating modes by the second control factor, and at higher modes - by the third.

The most significant effect on the margin of gasdynamic stability of the compressor has a change in fuel supply to the combustion chamber. This control factor can be used to remove the HPC from the surge when the influence of other means on the mode of operation of the compressor is insufficient.

Thus, the existing surge protection systems [4] include sensors that respond to the rate of change of air pressure behind the compressor and when the parameter is reached $A=\Delta p_{k} / p^{*}{ }_{\kappa} \Delta t \geq 7$, influencing the fuel-regulating equipment, reduce the engine operation mode to 0.7 nominal and switch on the "ENGINE SURGE" light board. Operating mode 0.7 nominal is chosen for the reason that it is in this mode in most engines the maximum margin of gas-dynamic stability of the compressor.

According to the developers of such a system, reduce the engine operating mode to the mode in which the condition $\Delta K_{y}=\Delta K_{\text {ммах }}$ is met, will eliminate the surge. This is only true in the event of a compressor surge in the presence of certain external disturbances. If the surge is caused by damage to the structural elements of the flowing part of the compressor or shading of the inlet device, then reducing the operating mode of the engine will not ensure the output of the compressor from the surge. In addition, this method of engine control cannot be recommended for modern GTE with a small combustion chamber volume. Small masses of air connected to the compressor do not allow eliminating the surge, if it has already begun.

Therefore, the proposed method of OL control at the stage when the surge has not yet developed, is the most promising for gas turbine engines of any type.

The functional diagram of the closed system of automatic control of the compressor of a low pressure of the two-shaft turbofan engine (TFE) is given in fig. 2, and the scheme of the closed ACS for HPC accordingly in fig. 3, where TS is a temperature sensor of the stagnant flow (TS); SS is the sensor of speed of an air stream (SS); SM is a sensor number $M$ air flow (SM); SD is a software device that generates the output and the maximum achievable for this mode of operation of the engine number $M$ of the air flow at the outlet of the compressor surge (SD); EC is an element of comparison of real and minimum numbers $M ; \Sigma$ is a mismatch signal amplifier; $\mathrm{EM}_{1}, \mathrm{KS}_{1}-$ the executive mechanism and the controlling body of the control system of the air bypass flaps from the 


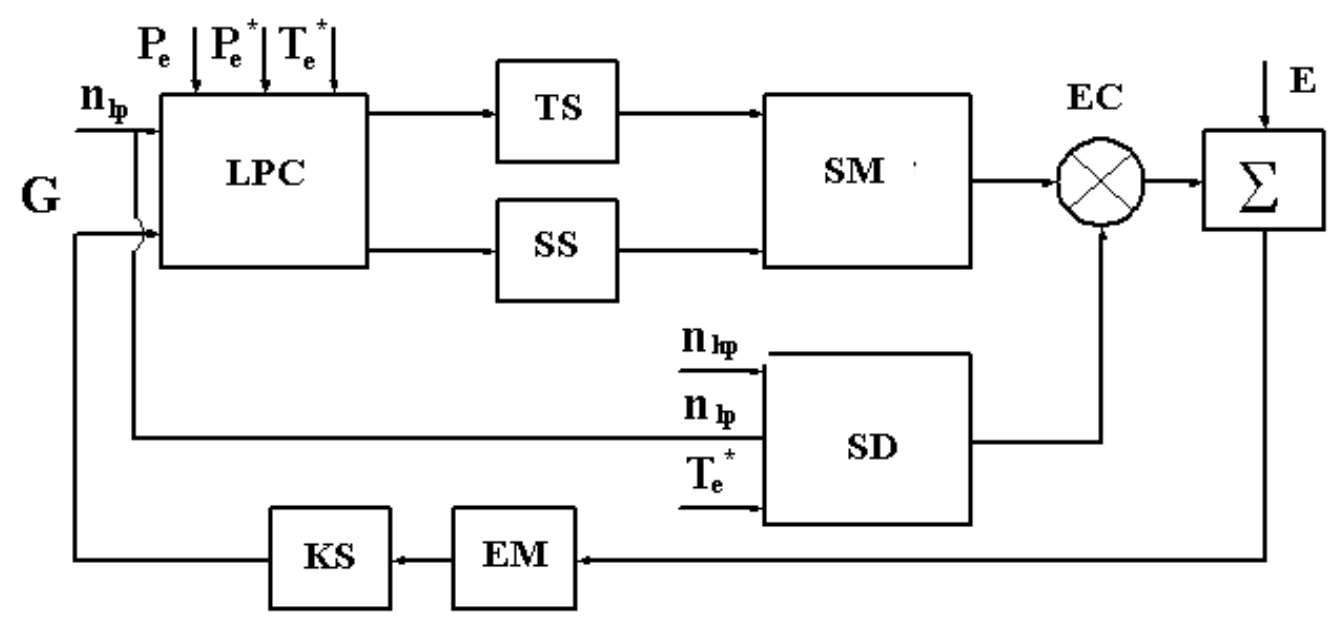

Fig. 2. Functional diagram of a closed ACS of a low pressure compressor

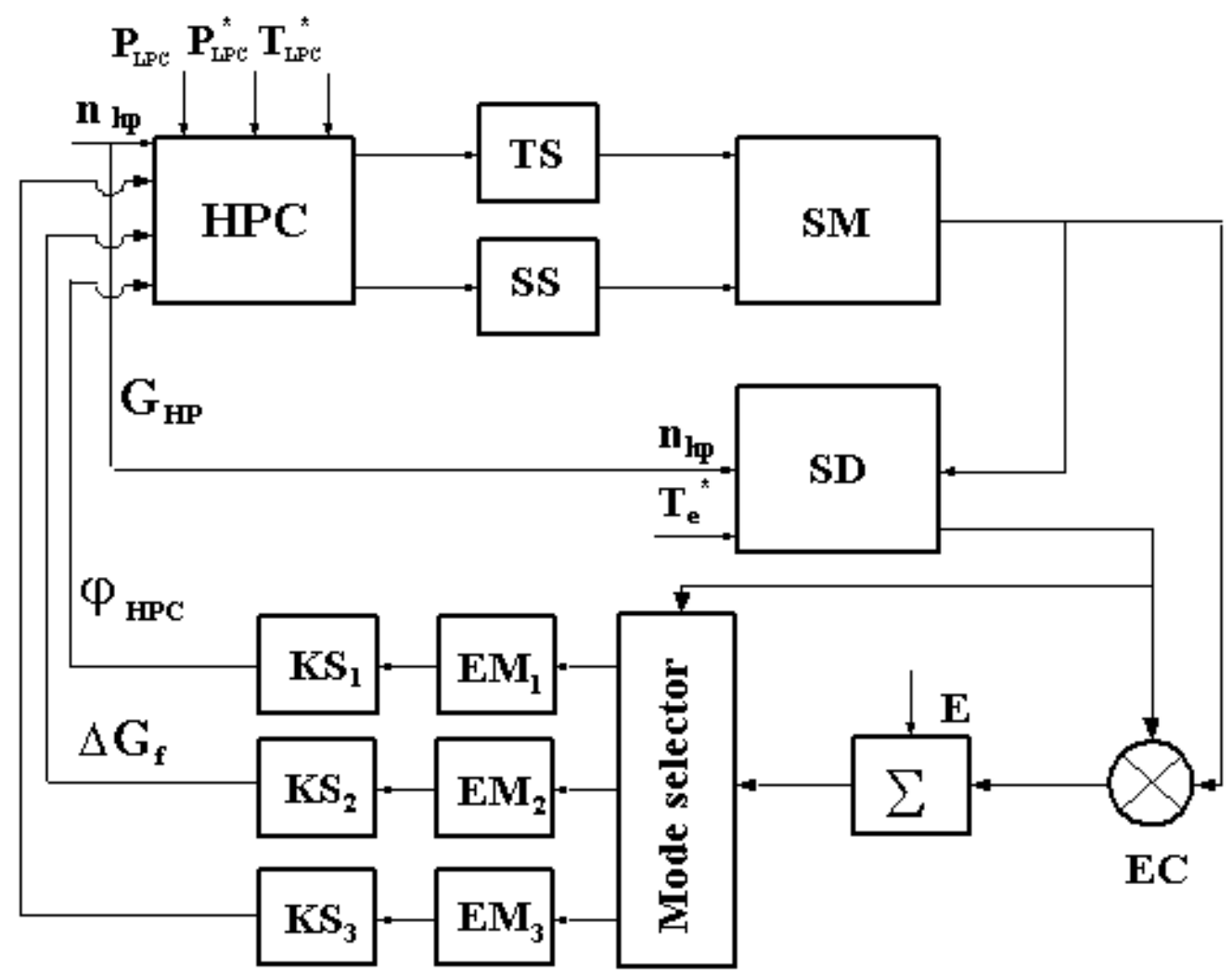

Fig. 3. Functional diagram of a closed ACS of a high pressure compressor

external circuit; $\mathrm{EM}_{2}, \mathrm{KS}_{2}$ - actuator and control body of the sash or air bypass valves due to the intermediate stages of the high pressure compressor; $\mathrm{EM}_{3}$, $\mathrm{KS}_{3}$ - the actuator and the control body of the system to reduce the supply of fuel to the combustion chamber during the surge of the HPC.

Control of OL of the compressor of low pressure is carried out by bleeding off air from a cavity on HPC in an external contour, and the minimum number $M$ at which this bleed off opens depends not only $\mathrm{n}_{l p}$ but also $n_{h p}$, that is, from the engine mode. The value of the minimum number $M$ can be obtained by calculation using the formula given in [7]

$$
\frac{p_{\kappa . m} / p_{\kappa .0}}{1-\frac{p_{k . m}}{p_{\kappa .0}}}<\frac{\frac{2}{k M^{2}} \frac{V_{N}}{V_{C}}-1}{4} .
$$

An example of the result of calculating the minimum values of the rupture $p_{k . m} / p_{k .0}$ the characteristics of the compressor that lead to the surge are shown in fig. 4. 


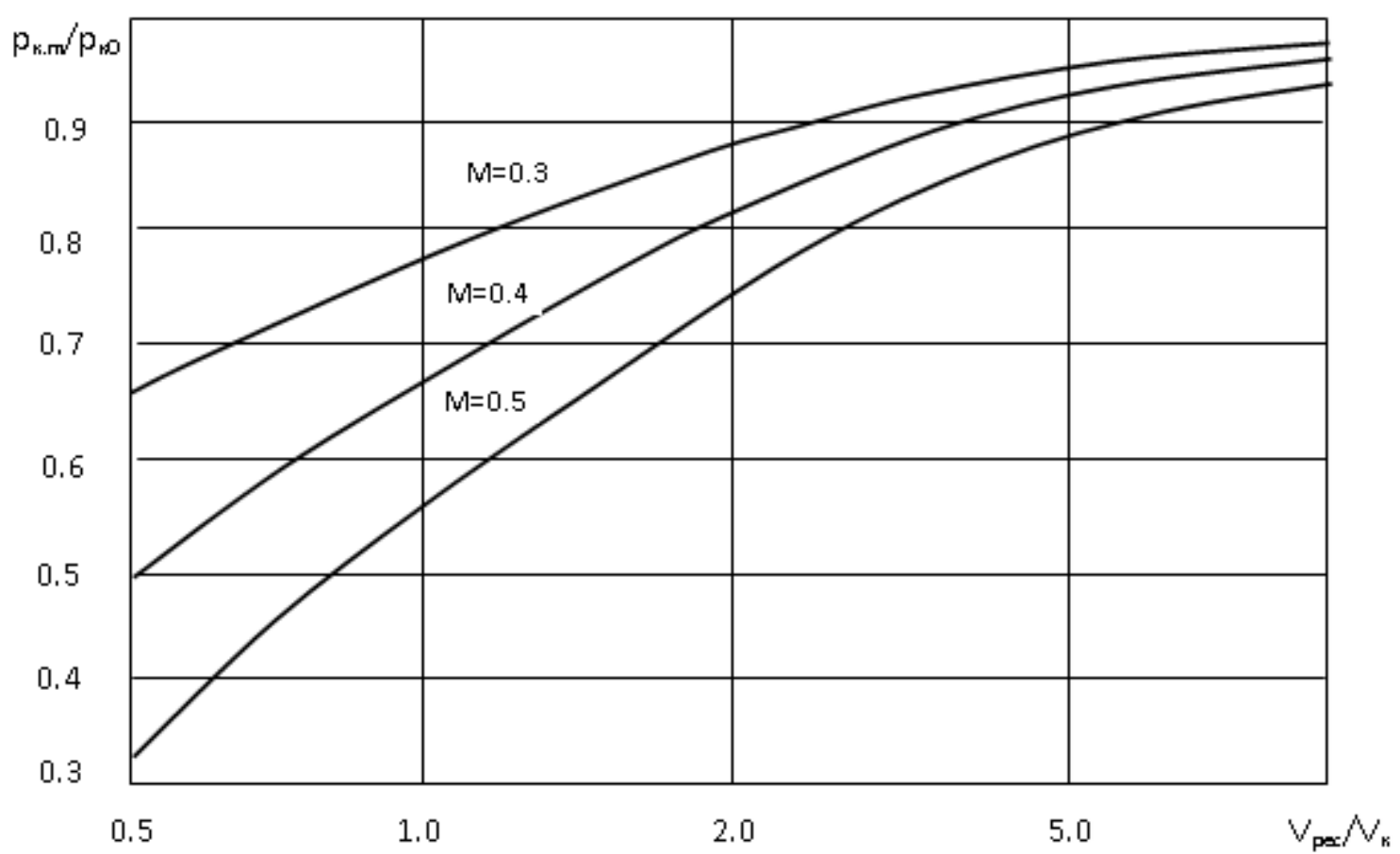

Fig. 4. Conditions of surge (reverse flow) in the compressor

These results show that the more connected the volume of the working fluid behind the compressor compared to its own volume, the smaller the rupture of the characteristics of the compressor, the reverse flow occurs. A similar result occurs when reducing the calculated flow rate in the compressor.

The amount of bleed off air into the outer circuit, including from the HPC (Fig. 4), can vary, providing $\Delta K_{y}=\Delta K_{y m i n}$. In this case, the reduction in engine thrust is negligible and occurs smoothly rather than discretely, as was the case with the relay control circuit of the air bleeding means. This engine control not only increases the level of flight safety, but also reduces fuel consumption.

The proposed OL position control system can be included as a component in the digital electronic ACS [8] of the engine, which will ensure its gasdynamic stable operation in the entire range of operating modes.

Synthesis of the anti-surge ACS device.

To prevent surges, a fragment of ACS, which allows detecting surges at an early stage is proposed. Below the theoretical references and directly a fragment of the ACS are proposed.

The loss of gas-dynamic stability of GTE compressors is preceded by pre-surge [5]. Pre-surge occurs when the compressor is operating on the left ascending branch of the characteristic, and the reason for its appearance is the presence of fluctuations in the flow, ie small deviations of parameters from their average values. For example, when operating the compressor stage on the left ascending branch of the characteristic, if the value of the relative flow velocity in front of the impeller blades is less than average, the pressure created by these blades will decrease, and there is a pre-surge.

The methods currently used make it possible to capture the surge, rather than the pre-surge, which reduces the time to remove the compressor from the breakdown mode and reduces the level of flight safety. Automatic control systems (ACS) are used to bring the compressor out of the breakdown mode, in which the opening of air bypass valves, change of installation angles of adjustable inlet guides and guide devices, change of fuel consumption are used as control factors [5].

Because surges lead to flight events, there is a need to develop devices for earlier detection. As the analysis of literature sources shows [1-7], research in the field of detection of pre-surge phenomena is very relevant.

The causes of pre-surge are changes in the geometric dimensions of the elements of the flow part of the gas turbine, uneven field parameters at the compressor inlet, non-stationary flow in transient modes, foreign objects entering the inlet device, failure of the supersonic inlet device, decreasing Reynolds number, increasing humidity. The most difficult task is to find diagnostic signs of parameters that would characterize the pre-surge state of GTE compressors.

In [2], the pre-surge is considered as the transition of the operating point across the boundary of 
the design margin of stability at a given mode of operation of the engine. The adiabatic efficiency of the compressor is considered as a diagnostic sign of pre-surge $\eta_{R}$. To determine its value, the following formula is used:

$$
\eta_{\kappa}=\frac{\left(\pi_{\kappa}^{* \frac{k-1}{k}}-1\right)}{\left(\frac{T_{\kappa}^{*}}{T_{6 x}^{*}}-1\right)},
$$

The instability boundary is set in the form of inequality;

$$
\eta_{\kappa}>A
$$

where $A$ - set limit value.

The essence of the method [2] is to determine the difference between the values of efficiency and the degree of pressure increase $\pi_{\kappa .2 p}^{*}$ on the border of stability and current values $\pi_{\kappa}^{*}$ and efficiency for a given reduced rotor speed. Variable $\Delta \eta_{k}=\left(\eta_{k .2 \mathrm{p}}-\eta_{k}\right)$ characterizes the possible margin of stability in terms of efficiency by the value of the constant in inequality (4). Time $\Delta t$, at which the operating point reaches the limit of stability, is determined by the rate of change of current values $\eta_{\kappa}, \pi_{x}$ and variables $\Delta \eta_{x}$, $\Delta \pi_{\kappa}=\left(\pi_{\kappa г p}-\pi_{\kappa}\right)$. Setting the value $\Delta t$, get the condition for the forecast of the surge:

$$
\begin{aligned}
& \left(\eta_{\kappa г p}-\eta_{\kappa}\right)>k_{1} \eta_{\kappa} ; \\
& \left(\pi_{\kappa г p}-\pi_{\kappa}\right)>k_{2} \pi_{\kappa},
\end{aligned}
$$

where $k_{1}, k_{2}$ - coefficients of proportionality.

The device for implementing this algorithm registers the values of pressures and temperatures of the stagnant flow at the inlet and outlet of the compressor and the speed of the rotor and includes a device for differentiation, multiple, two computing and limit devices. The signal from the output of the multiple device is formed by the usual reduction formula $n_{n p}=n \sqrt{288 / T_{6 x}^{*}}$. The limit device compares the values $\pi_{\kappa}$ and $\pi_{\kappa z p}$.

At the output of the first computing device, a value $\eta_{\kappa}$ is formed, and at the output of the second $-\eta_{\text {кер }}$, depending on the turnover frequency $n_{n p}$.

A pre-surge signal is generated when signals from both limit devices appear.

In the considered method of recognition of presurge phenomena on the basis of control of adiabatic efficiency of the compressor it is offered to use the worst limit of stability. However, during operation, as a result of the influence of several of the above factors, the shift of the stability limit may exceed the calculated value. In this case, the device operating according to algorithm (5) will detect the surge with a delay.
The disadvantage of this method is that the authors do not take into account the shift of the stability limit during operation due to the factors that cause pre-surge.

In [8] to determine the pre-surging state T-shaped pressure sensors are used, and which allow recording the rotational failure and determine whether or not there is a countercurrent. The beginning of the countercurrent corresponds to the zero value of the dynamic pressure on the T-shaped sensor.

The start of the surge can also be taken as the moment of increasing the pressure at the inlet to the compressor, which is fixed by the sensor. Time interval $\Delta \mathrm{t}$ from the beginning of the transient process or the occurrence of a rotational failure [2] to the occurrence of surges is calculated by the formula [3].

$$
\Delta t \approx \frac{l}{a} \frac{V_{N}}{V_{C}} \frac{1}{k M}\left[1-\sqrt{1-\frac{p_{\kappa . m} / p_{\kappa .0}}{\left(1-\frac{p_{k . m}}{p_{\kappa .0}}\right)} \cdot \frac{4}{\left(\frac{2}{k M^{2}} \frac{V_{N}}{V_{C}}-1\right)}}\right],
$$

where $l$ - compressor length; $M, a$ - the average length of the compressor Mach number and speed of sound; $V_{N}$ - network volume or output receiver; $V_{C}-$ compressor volume; $p_{\text {к. }}$ - the average pressure of the stagnant flow behind the compressor in steady-state operation immediately before the stability boundary; $p_{\kappa . M}$ - the average pressure of the stagnant flow behind the compressor after disturbance of steady work.

This time is for the compressors of aviation GTE and allows providing protection of the compressor from surges using electronic digital automatic control systems and autonomous servos of the air bleeding valves [8].

However, the use as a signal that would reflect the approach of the operating point to the limit of stability, the magnitude of the pressure drop or dynamic pressure has a number of disadvantages. In the case of reverse flow in a few milliseconds after the appearance of instability, the pressure behind the compressor has time to fall by only $3-5 \%$ of the original value [7]. The duration of the reverse flow is $20-30 \%$ of the surge period. The change in pressure by $3-5 \%$ coincides with the error of the measuring path, in this case the pre-surge will be recorded with some delay.

It is also worth noting that the pressure behind the compressor drops not only with the appearance of instability, but also when the combustion chamber is turned off or the restrictions in the ACS are triggered, which can lead to erroneous operation of the surge prevention system. Thus, it can be concluded that the most suitable signal to disrupt the steady operation of 
the compressor is to change the direction of flow rate behind the compressor. In this regard, the author proposes a scheme of the ACS fragment for early detection and prevention of surges (see Fig. 5), which uses an ionic anemometer as a speed meter, which allows us to determine the direction of flow [8].

The proposed method uses the fact that a measure of the flow rate in the ionic anemometer is the redistribution of current at electrodes 1 and 2. The means of ionization in the anemometer is a central electrode made in the form of a cylindrical rod having a region of curvature. According to the theory of corona effect, when a high voltage is applied from the power supply to the central electrode, a corona effect appears with the occurrence of a unipolar charge in the outer discharge zone between the central and two symmetrically arranged galvanically separated electrodes 1 and 2. Electrodes 1 and 2 receive unipolarly charged ions, the charge sign of which depends on the polarity of the voltage at the Central electrode.

At zero flow velocity as a result of volumetric pushing of the unipolar charge on electrodes 1 and 2 (Fig. 5) ions from the Central electrode fall evenly and the current is equal $\left(I_{1}=I_{2}\right)$. A measure of the flow rate is the redistribution of current at the electrodes depending on the magnitude of the speed and direction of flow.

At a steady current in the compressor as a result of attrition wear of ions there is a redistribution of current strength on electrodes, i.e current strength $I_{2}$ at electrode 2 becomes greater than the current load $I_{1}$ on the electrode $1\left(I_{2}>I_{1}\right)$.

The numerical value of the flow rate in the cross section at the outlet of the compressor stage is determined by formula (1).

The calculation of the speed is carried out in a computing device (Fig. 5), the signals to which come from the electrodes 1 and 3 through the matching device. The matching device provides signal encoding.

To prevent damage to the electronic units of the proposed device in the event of a breakdown in the ionic anemometer used supports $R_{1} \mathrm{i} R_{2}$, equal in value.

With a steady flow, the value of the flow velocity $\mathrm{c}$ has a positive value, and with the appearance

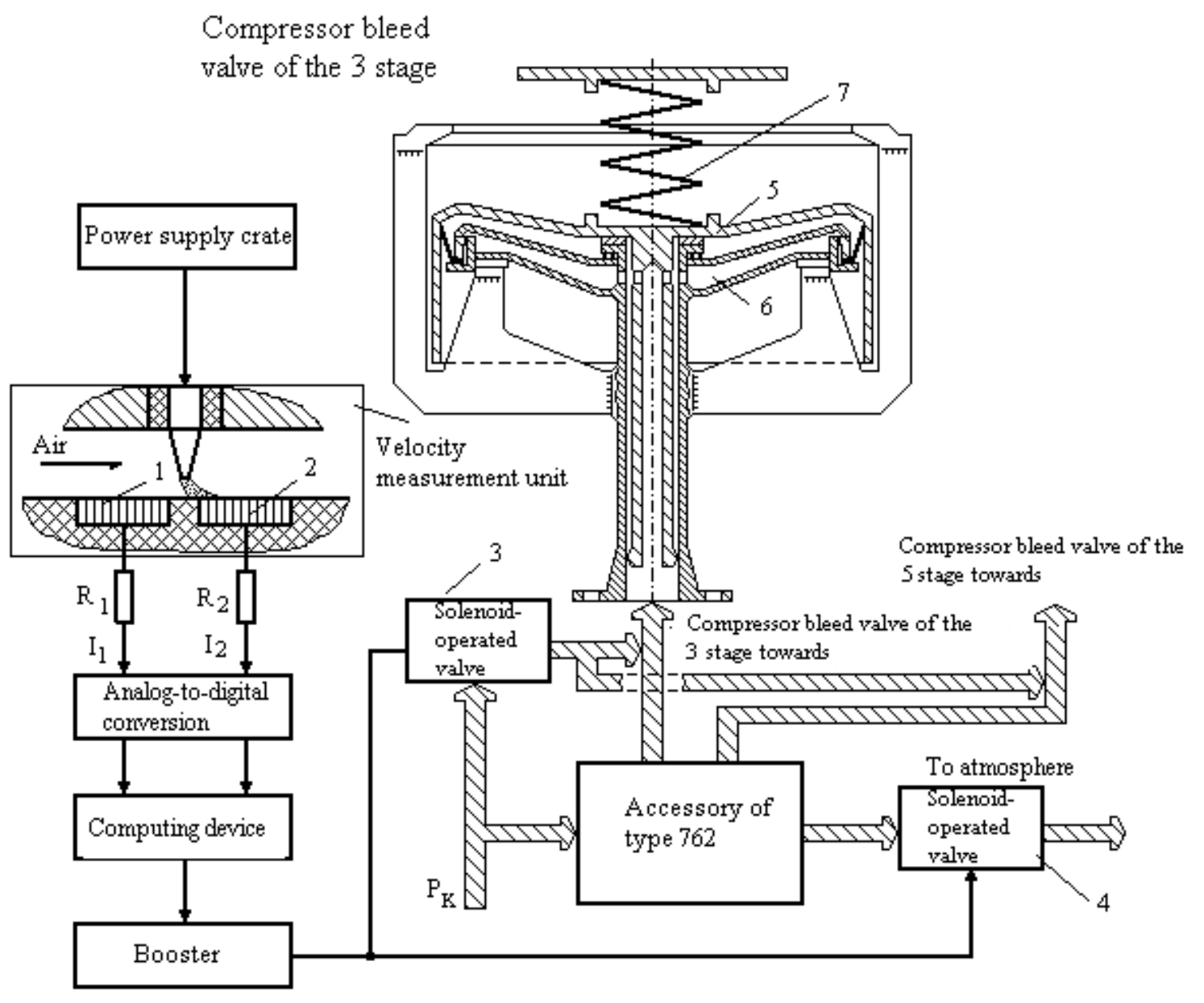

Fig. 5. Scheme of automatic surge warning device 
of instability, as indicated above, the direction of the flow changes. In this case $\left(I_{1}>I_{2}\right)$ the computing device generates an amplified signal and is fed to the solenoid valve 4 .

When the solenoid valve 4 is opened, the sealed cavities of the air bypass bleed valves installed in the 3rd and 5th stages of the high-pressure compressor are connected to the atmosphere, and the tributary 5 is squeezed by the spring 7 and the air bypass bleed valves open. After the normal operation of the compressor, when $\left(I_{2}>I_{1}\right)$, in the computing device, a signal is generated to open the solenoid valve 3 and close the valve 4 . When opening the valve 3 , the air taken from the compressor under pressure $p_{\kappa}$ is fed into the sealed cavities of the air bypass bleed valves 6 and they close.

If the engine has adjustable guides of the first stages of the high pressure compressor or adjustable propelling nozzle [1] and digital electronic ACS, for example, type FADEC [8], which implements the control principle for deviation of controlled parameters, the proposed device for measuring speed can be used in such a control system. In this case, it is possible to more effectively control the position of the line of operating modes, and hence the margin of stability of the compressors. At the steady operation of the compressor, control of valves of bypass bleeding of air is carried out by the accessory of type 762 MA in a regular mode depending on physical frequency of rotation of a rotor of a high pressure.

Conclusions. Methods are offered, and functional schemes of fragments of automatic control systems of GTE are developed, providing control of position of lines of working modes, on characteristics of cascades of compressors, and also allow to warn a surge at an early stage.

This system for recognition and prevention of pre-surge phenomena and, accordingly, surge, can be integrated into the digital electronic ACS aviation GTE [8], which performs the following operations:

- conversion of analog signals coming from sensors into discrete (digital) signals;

- calculation of values of inconsistency between measured and calculated values of controlled and limited parameters;

- conversion of digital values of control actions into analog electric signals;

- conversion of analog electrical signals into hydraulic signals;

The capabilities of the proposed system can be expanded by using a temperature sensor of the stagnant flow behind the compressor. That is, the developed combined device based on an ionic anemometer can be used both to solve the problem of determining the actual margin of gas-dynamic stability of the compressor stage and as a sensitive element of the ACS aviation GTE, which allow us to prevent surges.

\section{References:}

1. Кулик Н.С. Параметрические методы оценки технического состояния авиационных ГТД. Киев : КИИГА, 1993. 139 с.

2. Осик В.М., Панін В.В., Хаммуд Н. Оцінка впливу зміни геометричних розмірів елементів ГТД в експлуатації на його газодинамічну стійкість. Вісник Київського міжнародного університету изивільної aвiauiiï. 1999. № 1. С. 15-20.

3. Волянська Л.Г., Панін В.В., Гаоюн Сунь. Методи і засоби підвищення газодинамічної стійкості компресорів газотурбінних двигунів : монографія. Київ : НАУ, 2005. 200 с.

4. Зимон А.Д. Адгезия жидкости и смачивание. Москва : Химия, 1974. 416 с.

5. Горбановский В.Б., Панин В.В., Чумак О.И. Методика количественной оценки загрязнений элементов проточной части ПС-90А. Киев : КИИГА, 1990. 79 с.

6. Петунин А.Н. Методы и техника измерений параметров газового потока. Москва : Машиностроение, 1996. 380 c.

7. Терещенко Ю.М., Мітрахович М.М. Авіаційні газотурбінні двигуни. Київ : КВІЦ, 2001. 312 с.

8. Olali N.V., Olali M.O., Orukari M., Jumbo E.E. A model of compressor blades contamination in aviation GTE in operation. Вчені записки Таврійського начіонального університету імені В. І. Вернадського. 2018. № 6. Vol. 29 (68).

\section{ОЛалі Н.В., Осайсай Е.Ф., Олалі М.О. СИНТЕЗ АВТОМАТИЧНОЇ СИСТЕМИ АНТИПОМПАЖНОГО ЗАХИСТУ АВІАЦІЙНОГО ГТД}

Газодинамічна стійкість компресорів авіачійних газотурбінних двигунів є однію з найважливіших умов, що визначає їх надійність і рівень безпеки польотів. Помпажні явища в ГТД призводять до втрати тяги, супроводжуються зростанням температури газів перед турбіною і підвищенням рівня вібрацій і масових витрат по тракту двигуна. У роботі допускається невелика ймовірність виникнення помпажа, але запропоновано обладнати ГТД аварійними системами антипомпажного захисту. 
Під час створення високонапірних компресорів особливу увагу приділяють забезпеченню високого ККД та необхідного запасу газодинамічної стійкості у всьому діапазоні зміни режимів роботи ГТД в прочесі експлуатачії. Вирішення иієї задачі за збереження великих значень ступенів підвищення тиску в компресорі пов'язане з необхідністю забезпечити оптимальне протікання лінії робочих режимів на характеристиці компресора двигуна. Під час створення автоматичної антипомпажної системи використано як керуючий фактор зміну подачі палива в камеру згоряння двигуна, оскільки він має найбільш значний вплив на запас газодинамічної стійкості компресора.

Запропонована система керування положенням лінії робочих режимів, що може бути включена як компонент у иифрову електронну систему автоматичного керування двигуна, що забезпечить його газодинамічно стійку роботу у всьому діапазоні експлуатаџійних. Для попередження помпажу пропонується автоматичний пристрій, щьо дозволяє виявляти помпаж на ранній стадії-передпомпаж. У роботі передпомпаж розглядається як перехід робочої точки через границю розрахункового запасу стійкості на цьому режимі роботи двигуна. В якості діагностичноїознаки передпомпажса розглядають адіабатичний ККД компресора. Пристрій для реалізачії иього алгоритму реєструє величини тисків $i$ температур загальмованого потоку на вході і виході з компресора і частоту обертання ротора. Для вимірювання швидкості потоку пропонується використовувати іонний анемометр.

Можливості пропонованої системи можуть бути розширені при використанні датчика температури загальмованого потоку за компресором. Тобто розроблений комбінований пристрій на базі іонного анемометра може бути використаний як для вирішення завдання визначення фактичного запасу газодинамічної стійкості каскаду компресора, так і в якості чутливого елемента системи керування авіаційних ГТД, які дозволяють попереджати помпаж.

Ключові слова: авіаційний газотурбінний двигун, помпаж, передпомпаж, газодинамічна стійкість, лінія робочих режимів, автоматичний пристрій попередження помпажу. 